УДК 355.48:327.5(410+82)“1982”

DOI: $10.33099 / 2707-1383-2020-38-4-284-294$

\author{
Андрух 0.O., магістр \\ державного управління, здобувач, \\ Національний університет оборони України \\ імені Івана Черняховського \\ (м. Київ, Україна) \\ ORCID: https://orcid.org/0000-0002-3594-5499
}

\title{
ОСОБЛИВОСТІ ВЕДЕННЯ ПРОТИПОВІТРЯНОЇ ОБОРОНИ КОРАБЕЛЬНИМИ УГРУПОВАННЯМИ В АНГЛО-АРГЕНТИНСЬКОМУ ЗБРОЙНОМУ КОНФЛІКТІ 1982 РОКУ
}

\begin{abstract}
Розкрито й узагальнено досвід організації протиповітряної (протиракетної) оборони кораблів Великобританії у Південній Атлантиці під час англо-аргентинського збройного конфлікту 1982 року. 3'ясовано, щзо для успішного ведення воєнних дій на морі корабельне угруповання має мати надійну систему протиповітряної оборони, яка повинна включати авіаційні засоби дальнього виявлення цілей на малих висотах. Показано дії британського корабельного угруповання на рубежах протиповітряної оборони, тактичні прийоми та результати використання різних засобів ураження повітряного противника. Цей конфлікт засвідчив важливість завчасного попередження про повітряну небезпеку та взаємопов'язану і дієву радіоелектронну та повітряну розвідку при вирішенні завдань протиповітряної оборони.
\end{abstract}

Ключові слова: англо-аргентинський збройних конфлікт 1982 р., засоби повітряного нападу, протиповітряна оборона, протиракетна оборона, ешелонування системи ППО.

Постановка проблеми. Досвід локальних війн і збройних конфліктів другої половини XX - початку XXI ст. виявив стійку тенденцію до набуття збройною боротьбою міжвидового (міжвідомчого) характеру і створення міжвидових угруповань військ (сил) різних рівнів - угруповань військ (сил), до складу яких, відповідно до характеру конфлікту, умов конкретного театру воєнних дій (ТВД) і поставлених завдань, входили об'єднання, з'єднання та частини від усіх видів збройних сил, а також сили і засоби інших силових відомств держав. Їх застосування виявилося надзвичайно ефективним і доцільним в оперативному й економічному відношенні, що свідчить про перспективність, а можливо,

й необхідність вести збройну боротьбу iз застосуванням саме таких угруповань військ (сил). 3 огляду на це найбільш показовим $€$ англо-аргентинський збройний конфлікт 1982 року.

На морському ТВД у Південній Атлантиці флоти протиборчих країн для знищення сил флоту противника застосовували різні види морської зброї, бойової техніки та озброєння, апробовували нові форми та способи ведення воєнних дій. Тому кораблям і з'єднанням військово-морських сил (ВМC) як Великобританії, так і Аргентини, доводилось вести різні бойові дії із протиповітряної (ППО), протиракетної (ПРО), протимінної та протичовнової оборони противника. 
В аспекті обраної теми зазначимо, що ППО сил флоту — це комплекс заходів і бойових дій з відбиття нападу повітряного противника, прикриття сил у морі та пунктах базування, а також берегових об'єктів флоту від ударів 3 повітря. ППО здійснюється силами флоту самостійно й у взаємодії з силами та засобами ППО інших видів збройних сил. Основу ППО складають зенітні вогневі корабельні й берегові засоби, а також винищувальна авіація ВМС. Складовою частиною ППО флоту є протиракетна оборона, яка призначена для боротьби з ракетами різного призначення, що застосовуються противником з кораблів, літальних апаратів та берегових установок (Военно-морской словарь. 1990, с. 347; Военный энциклопедический словарь. 1983, с. 344).

Аналіз останніх досліджень і публікацій. Дослідженню різних аспектів англо-аргентинського збройного конфлікту 1982 р. і діям флотів у локальних війнах i збройних конфліктах другої половини $\mathrm{XX}$ ст. присвячено низку праць, зокрема вітчизняних дослідників Ю. Бадаха (Бадах, Ю. Г. 2003), Д. Татаркова (Татарков, Д. 2007; Татарков, Д. Б. 2013) і І. Фурмана (Фурман, I. I. 2006). Стаття за авторством Ю. Галкіна (Галкин, Ю. 1983) присвячена веденню безпосередньо ППО англійськими експедиційними силами в англо-аргентинському конфлікті. У працях Б. Родіонова, Є. Нікітіна та Н. Новічкова (Родионов, Б. И. \& Новичков, Н. Н. 1987; Родионов, Б. \& Никитин, Е. \& Новичков, Н. 1983) розкриваються питання застосування крилатих ракет і ведення радіоелектронної боротьби (РЕБ) у Південній Атлантиці під час війни 1982 р. Стаття А. Рябчикова (Рябчиков, А. В. 2001) присвячена застосуванню протикорабельних ракет (ПКР) у локальних війнах, зокрема й Фолклендській війні 1982 р. Деякі питання забезпечення стійкості корабельних з'єднань у морі розкрива- ються у праці І. Хурса (Хурс, И. К. 1987) та ін.

Мета статті полягає у розкритті й узагальненні досвіду організації протиповітряної (протиракетної) оборони британських експедиційних сил під час англо-аргентинського конфлікту 1982 р.; показати дії британського корабельного угруповання на рубежах протиповітряної оборони, їх тактичні прийоми та результати використання різних засобів ураження повітряного противника.

Виклад основного матеріалу. Досвід збройної боротьби на морі свідчить, що проблема оборони кораблів і з'єднань ВМС від засобів повітряного нападу противника $є$ дуже складною. Неналежне ставлення до ППО має трагічні наслідки, які призводять до значних втрат у живій силі та техніці. Найбільш показовим з точки зору ведення корабельним угрупованням ППО $\epsilon$ англо-аргентинський збройний конфлікт 1982 р. У цьому конфлікті з обох сторін були задіяні біля 350 бойових літаків і вертольотів, що складали суттєву загрозу силам флотів. Втрати в корабельному складі під час конфлікту від дій авіації були найбільшими за всю повоєнну історію локальних війн. Сумарний тоннаж потоплених кораблів склав понад 50 тис. тонн (Фолклендская война. 1982). Саме тому ППО розглядалась як одне із головних завдань у збройній боротьбі на морі.

Найбільших втрат від дій авіації у боях за Фолклендські острови, насамперед у корабельному складі, зазнали британські ВМС. Королівський флот Великої Британії втратив 6 кораблів і понад 10 - отримали значні пошкодження (Хурс, И. К. 1987, с. 34). Головною причиною цього стала недостатня надійність ППО направленого в район конфлікту корабельного угруповання. Вона будувалася за зональним принципом i передбачала ешелоноване використання 
засобів розвідки та РЕБ, палубних літаків i вертольотів, корабельних та наземних зенітно-ракетних (ЗРК) і артилерійських комплексів. При організації ППО командування ВМС Великої Британії враховувало радіуси дій аргентинських і британських літаків, а також віддаленість островів від материка (Галкин, Ю. 1983, с. 65).

Для забезпечення захисту експедиційних сил (кораблів і сил десанту) від атак аргентинської авіації командування британських ВМС у морській зоні Фолклендських островів створило систему ППО (Татарков, Д. Б. 2013, с. 12) у три рубежі. На першому, дальньому рубежі ППО, есмінці та фрегати 3 керованою ракетною зброєю (КР3) по черзі парами виконували функції кораблів радіолокаційного дозору (РЛД) і патрулювали в загрозливому секторі на лінії віддалення 216 миль (400 км) західніше від Фолклендських островів. Обладнані пошуковою радіолокаційною станцією (РЛС) 965R, кораблі забезпечували виявлення аргентинських літаків, що летіли на середніх і великих висотах (на середніх висотах — в радіусі 120 миль, а на малих - до 27 миль (50 км) (Галкин, Ю. 1983, с. 65)), на відстані біля 250 миль (460 км) від островів, тобто через короткий проміжок часу після їх вильоту 3 континентальних аеродромів. Повітряне прикриття району забезпечували літаки 3 вертикальним або зі скороченим зльотом і посадкою "Sea Harrier", що базувались на авіаносцях "Invincible" i "Hermes". Чергова пара літаків “Sea Harrier", баражувала за 260 миль (480 км) західніше від авіаносців. Зміну літаків повітряного патруля виконували через кожні 40 хвилин. На літаки 3 кораблів РЛД передавали цілевказівки про виявлені аргентинські літаки. На випадок подолання аргентинськими літаками даного рубежу з авіаносців піднімали чергову пару літаків, що знаходилась у трихвилинній готовності до зльоту. В дію вступали й зенітно-ракетні комплекси (ЗРК) “Sea Dart" (дальність стрільби 70 км) кораблів з'єднання. Забезпечуючи ППО з'єднання, літаки “Sea Harrier" за потреби виконували зліт i посадку на вертолітні майданчики найближчих кораблів охорони, заправлялись паливом і знову піднімались у повітря для продовження чергування в складі бойових патрулів.

На другому, середньому рубежі оборону авіаносців здійснювали корабельні групи, які діяли в блокадній зоні поблизу Фолклендських островів: легкі крейсери типу “County" з ЗРК "Sea Slug” $(1 \times 2$ кормова пускова установка 3 ракетами "Sea Slug”) i GWS22 (2×4 носова і кормова пускові установки з ракетами "Sеа Сат") та есмінці КР3 типу "Sheffield" з ЗРК GWS30 (1×2 кормова пускова установка з ракетами “Sea Dart”), a також літаки "Sea Harrier” з групи повітряного прикриття (Родионов, Б. И. \& Новичков, Н. Н. 1987, с. 145-146). Для відбиття масованих нальотів використовували корабельні зенітні артилерійські системи. Крім того, застосовували вертольоти в якості постановників пасивних перешкод або інфрачервоні пастки, що протидіяли головкам самонаведення (ГСН) авіаційних керованих ракет класу «повітря-поверхність" (Галкин, Ю. 1983, с. 65).

Третій, ближній рубіж охоплював простір над північною частиною Фолклендської протоки і бухтою порту Сан-Карлос. На цьому рубежі перехоплення аргентинських літаків вели фрегати КРЗ типу "Broadsword", оснащені ЗРК GWS25 (2×6 носова і кормова пускова установка 3 ракетами “Sea Wolf”), спеціально призначені для стрільби по низько літаючим цілям, а також фрегати типу “Amazon” з ЗРК GWS22 $(1 \times 4$ кормова пускова установка з ракетами "Sea Caт") i "Leander" із ЗРК аналогічного типу ( $3 \times 4$ носова і дві кормові пускові установки). Всі ці кораблі мали на озброєні 20-мм 
i 40-мм автомати. При висадці десанту, коли виникла потреба прикривати британські війська в районі захопленого плацдарму, система ППО була дещо змінена. Перший, дальній рубіж забезпечували кораблі з ЗРК GWS30 i “Sea Slug”, а також літаки вертикального зльоту “Sea Harrier”, що безперервно патрулювали біля західного узбережжя Фолклендських островів на декількох загрозливих напрямках. Авіаносці були відведені на 100 миль південно-східніше островів, а 12 есмінців і фрегатів КР3 введені в Фолклендську протоку. Розташувавшись у південно-східній їі частині, вони виконували завдання ППО авіаносців на другому рубежі й одночасно прикривали десант (Родионов, Б. И. \& Новичков, Н. Н. 1987, с. 146-147). Прикриття військ від атак з повітря під час їх висадки і ведення бойових дій за розширення плацдарму здійснювали й ЗРК “Rapier” (дальність стрільби до 7 км) i “Blowpipe” (переносний, з максимальною дальністю перехоплення 3 км) (Галкин, Ю. 1983, с. 65).

Для забезпечення ППО цивільних суден, які направляли в район ведення бойових дій, британці встановлювали на них ЗРК та артилерійські зенітні автомати (40-мм "Bofors" і 20-мм "Oerlikon") (Бадах, Ю.Г. 2003, c. 150).

Можна стверджувати, що створенням глибокоешелонованої системи ППО командування Королівських ВМС досягло певних позитивних результатів. Так, збільшення зони радіолокаційного виявлення змусило аргентинських льотчиків здійснювати прорив до цілі і долати значну частину маршруту на малих висотах, що значно ускладнювало виконання бойових завдань. Через велику витрату палива обмежувався радіус польоту аргентинських літаків і різко знижувались їх можливості при розвідці та знищенні британських кораблів. Через це і повітряні бої носили обмежений за часом характер. Нерідко аргентинські льотчики поверталися на свої аеродроми, тільки частково виконавши завдання щодо завдання ударів по кораблях і силах десанту противника (Галкин, Ю. 1983, с. 65). Літаки 3 вертикальним зльотом і посадкою, які мали високу маневреність, зарекомендували себе як дуже ефективний засіб ППО. Ними знищено 31 аргентинський літак. Зенітними ракетними й артилерійськими комплексами кораблів загалом збито 25 літаків противника (Фурман, I. I. 2006, арк. 116).

Слід зазначити, що велику роль у ППО кораблів відіграли ЗРК, на долю яких приходилося понад 50\% збитих літаків і вертольотів.

Особливо високі бойові можливості показав ЗРК “Sea Wolf”, на бойовому рахунку якого п'ять збитих літаків і дві ПКР “Ехосеt”. Основне завдання комплексу - це боротьба з цілями, що летять на низькій висоті та мають ефективну відбиваючу поверхню до 0,1 м². Командування британських ВМС розташовувало кораблі з ЗРК "Sea Wolf" на загрозливих напрямках у ближній зоні ППО авіаносців. Саме iз ЗРК "Sea Wolf" аргентинські льотчики намагались уникнути зустрічі, оскільки при атаках на кораблі, оснащені ЗРК подібного типу, ланками у складі чотирьох штурмовиків типу “Skyhawk” у середині травня кожна ланка втрачала половину літаків, інші ж, намагаючись вразити кораблі з протиракетного маневру, бомбардували неточно (Рябчиков, А. В. 2001). Однак, при бойовому використанні комплексу виявили й серйозні недоліки. Через те, що кут місця цілі складав менше $1,5^{0}$, використовувати РЛС супроводу цілі і ракети було вкрай складно. Крім того, виявилось, що ЗРК "Sea Wolf" не пристосований для ураження цілей, які йдуть на корабель із різних напрямків. При цьому пускову установку ставили в середнє положення, що вимагало повторного 
процесу підготовки й опрацювання даних для стрільби (Бадах, Ю.Г. 2003, с. 151).

Хоча основним ЗРК кораблів британських експедиційних сил був комплекс “Sea Dart”, проте, він мав дуже низькі бойові можливості (значну мертву зону в 4,5 км i час реакції 20 сек.). Знаючи це, аргентинські льотчики виконували атаки 3 малих висот, виключаючи таким чином стрільбу ракетами "Sea Dart". Крім того, комплекс був малопридатним для боротьби з груповими цілями і РЛС типу «909». Також ЗРК “Sea Dart" не забезпечував точними даними при стрільбі в умовах сильного хвилювання моря. Помилки у визначенні дистанції до цілі доходили до 16 км.

Результативною виявилась участь у війні фрегату "Plymouth": 3 корабля за час конфлікту було випущено 9 зенітних ракет "Sea Сат" і зроблено 900 пострілів із 114мм гармат, як результат, було збито 5 і пошкоджено декілька аргентинських літаків (Фолклендская война. 1982).

Разом 3 позитивними моментами в організації ППО кораблів британських експедиційних сил варто звернути увагу і на іiі слабкі місця. Так, забезпечуючи ППО, кораблі РЛД самі ставали вразливими від атак аргентинських літаків. Так, наприклад, 4 травня $з$ двох випущених ракет "Ехосеt" одна влучила в есмінець КРЗ "Sheffield", унаслідок чого корабель затонув. Другу ракету з фрегату КР3 “Plymouth" виявили завчасно, за 40 хв. Завісою з дипольних відбивачів були створені пасивні перешкоди, що відвели ПКР у хибному напрямку (Родионов, Б. \& Никитин, Е. \& Новичков, Н. 1983, с. 89; Татарков, Д. 2007, с. 182-183). Приклад 3 есмінцем КР3 “Sheffield" показав, що навіть так звані універсальні надводні кораблі мали порівняно невисоку бойову стійкість від ударів засобів повітряного нападу, особливо ПКР з низькою траєкторією польоту. Наведені факти свідчать, що для успішного вирішення завдання з ППО потрібно комплексне використання різних засобів РЕБ і повністю автоматизовані зенітні, ракетні та артилерійські системи 3 малим «часом реакції», високою щільністю вогню та здатних уражати цілі на малих висотах.

Відсутність літаків дальнього радіолокаційного виявлення та винищувачів-перехоплювачів дальньої дії не дозволяло своєчасно виявляти повітряного противника і перехоплювати його в дальній від авіаносних багатоцільових груп зоні. Цей чинник і вплинув на тактику дій аргентинської авіації. Так, при очевидній якісній перевазі британських ВМС, найбільш підготовлені аргентинські льотчики успішно долали протидію засобів ППО кораблів і винищувачів, здійснюючи польоти з продуманим маневруванням на малих та обмежено малих висотах. Під час атак вони часто заходили з боку берега або сонця, ускладнюючи тим самим роботу операторів і навідників. У наслідок таких несподіваних і ефективних атак були потоплені есмінці КРЗ “Sheffield” i “Coventry”, фрегат КР3 “Antelope”, декілька кораблів отримали серйозні пошкодження.

Певну слабкість ППО виявили при відбитті нальотів авіації аргентинських військово-повітряних сил на сили десанту під час висадки в районі порту Сан-Карлос, яку прикривала група фрегатів, озброєних ЗРК “Sea Dart” i “Sea Wolf”. Скупченість британських кораблів у вузькій Фолклендській протоці дозволила аргентинським льотчикам здійснити низку успішних атак, унаслідок чого два фрегати КР3 (“Ardent” i “Antelope”) були потоплені, а декілька інших кораблів отримали серйозні пошкодження. Аргентинська авіація при цьому втратила шість літаків (Галкин, Ю. 1983, с. 65).

Загибель есмінця КР3 "Sheffield" і деяких інших бойових кораблів спонукало 
командування британських експедиційних сил активніше боротись з ПКР, широко застосовуючи для цього засоби РЕБ. Кораблі британського флоту майже безперервно виставляли хмари загороджувальних пасивних перешкод, якщо виникала небезпека чи навіть підозра на загрозу повітряного нападу. Через це витрачалась значна кількість пасивних радіолокаційних відбивачів, що змушувало підприємства британської фірми "Plus Aerospace" (основного постачальника) працювати протягом місяця цілодобово і без вихідних днів. Однак, у деяких випадках засоби радіоелектронної протидії (РЕП) були безсилими, оскільки скидання та стрільба некерованими ракетними снарядами (НКРС) здійснювалась, як і в роки Другої світової війни - за даними візуального спостереження. Так, наприклад, 21 травня був потоплений фрегат КРЗ “Ardent”, що вів артилерійський вогонь по позиціям аргентинських військ у районі Сан-Карлоса. Спочатку він спільно з іншими кораблями групи успішно відбив атаки поршневих літаків "Pukara", реактивних штурмовиків "Mirage III", а потім потрапив під вогонь НКРС і бомб легких штурмовиків “Aermacchi”. Атака аргентинських літаків на кораблі проводилась 3 різних напрямків, що значно ускладнювало виконання завдань ППО (Родионов, Б. \& Никитин, В. \& Новичков, Н. 1983, с. 78,81$)$.

При відбитті атак повітряного нападу противника, який застосовував сучасні ПКР, британці використовували різні типи НКРС, начинені дипольними відбивачами, виготовленими 3 металізованого скляного волокна, алюмінієвої фольги та інших матеріалів. За нормальних метеоумов час дії пасивних перешкод складав 6 хв. (Бадах, Ю.Г. 2003, с. 150). Для формування хмари перешкод застосовували й механічні прилади розкидання пакетів радіовідбивачів у потоки повітря. Піротехнічні системи не використовували, оскільки це призводило до спайки та скручування елементів, їх обважніння i, як наслідок - до пришвидшеного зниження хмари перешкод. 3 метою збільшення часу зависання хмари форма відбиваючих елементів при вільному польоті в потоках повітря забезпечувала їх обертання під кутом $45^{0}$ відносно вертикальної вісі, що сприяло нейтралізації захисних якостей ГСН. Це визначалося ще й тим, що деякі головкою самонаведення ПКР для більшого захисту від перешкод реагують лише на одну складову відбиваючої радіохвилі — лише з вертикальною або лише з горизонтальною поляризацією.

Варто зазначити, що високу ефективність у боротьбі з крилатими ракетами, що самі наводяться на ціль, показали активні i пасивні засоби РЕП. Для протиракетного захисту на кораблях експедиційних сил ВМС Великої Британії застосовувались три тактичні прийоми постановки перешкод: активних, пасивних або комбінованих пасивних та активних.

Перший тактичний прийом полягав у постановці маскувальних перешкод і призначався для зменшення ймовірності захоплення ГСН корабля, який захищався, при груповій атаці ПКР.

Корабель, що атакований ПКР, під час знаходження ракети на дальності 1-2 км від корабля, створював до чотирьох хмар пасивних перешкод. Зміна висоти і дальності хибних цілей забезпечувалась ручною установкою часового дистанційного механізму скидання головної частини НКРС. Частина ракет могла спрацювати по пасивним перешкодам, а перехоплення інших забезпечували корабельні засоби самооборони. Механізм розкидання пакетів радіовідбивачів при спільній постановці маскувальних перешкод з НКРСами зазвичай спрацьовував із затримкою 7 сек. після відстрілювання НКРС. 
Такого типу перешкодами прикривали британські кораблі при масованому нальоті аргентинської авіації, коли був потоплений контейнеровоз “Atlantic Conveyor". Так, 25 травня аргентинська авіація завдала ракетного удару по протичовновому авіаносцю "Hercules". Після виявлення літаків британські кораблі (за іншими даними, 3 піднятих у повітря вертольотів (Рябчиков, Ю. 2001)), які знаходились в охороні, виставили велику кількість пасивних перешкод - дипольних відбивачів. Унаслідок ПКР “Ехосеt” відхилилась праворуч авіаносця, іiі ГСН серед великої кількості перешкод знайшла ціль 3 більшою відбиваючою здатністю — контейнеровоз "Atlantic Conveyor” (Татарков, Д. 2007, с. 270). Приклад із судном наочно засвідчив, що поспішне формування хмари пасивних перешкод при організації захисту від ПКР без урахування побудови ордера на даний час може призвести не тільки до дезорієнтації ракети, але й захоплення іiі ГСН корабля, що знаходиться поблизу.

Другий тактичний прийом полягав у зриві автоматичного супроводження цілі головкою самонаведення ПКР після їі захоплення. Він передбачав постановку відвідних пасивних перешкод 3 одночасним виконанням атакованим кораблем протиракетного маневру. Цей прийом застосовувався на випадок пізнього виявлення ракети, що наближалась до корабля, коли для організації ПРО залишалося дуже мало часу. У безпосередній близькості від корабля на дальності до 100 м створювалася хмара пасивних перешкод таким чином, щоб вона i корабель знаходились посередині спроби активної радіолокаційної ГСН по дальності. Як наслідок, ракета відхилялась від центру ваги корабля і відводилась на хмару перешкод, що мала велику ефективну площу розсіювання, а корабель виходив з хмари пасивних перешкод, виконуючи проти- ракетний маневр. Такий прийом застосував есмінець КР3 “Glamorgan”, який 12 червня вів обстріл позицій аргентинських військ у районі Порт-Стенлі, з наземної пускової установки був нанесений ракетний удар чотирма ракетами “Exocet” АM.40. На есмінці встигли виставити пасивні відвідні перешкоди, і на корабель вийшла лише одна ракета, що влучила в кормову надбудову. Були виведені із строю вертолітний майданчик і ангар, але есмінець залишився на плаву.

Третій тактичний прийом передбачав спільне використання пасивних та активних засобів РЕП. Корабель, який виявився у спробі активної радіолокаційної ГСН по дальності, запускав НКРС із зарядом дипольних відбивачів, включав станцію активних перешкод, що працювала в режимі відведення ракети на хмару пасивних перешкод (хибну ціль).

Оскільки ракета "Ехосеt" має ГСН, яка забезпечує самонаведення на станцію активних перешкод, тому системами постановки перешкод (бортовими приймачами попередження про радіолокаційне опромінення, автоматами скидання дипольних відбивачів та інфрачервоними пастками) також оснащували британські літаки та деякі типи вертольотів.

Важливо зазначити, що завдяки своєчасному застосуванню пасивних перешкод жоден літак “Sea Harrier” FRS1 не був збитий ракетами з радіолокаційними ГСН (наземних ЗРК). У ході бойових дій британські літаки застосовували й активні радіоелектронні перешкоди, які успішно застосовувались проти РЛС управління вогнем зенітної артилерії (Фурман, I.I. 2006, арк. 123). Так, апаратурою постановки таких перешкод, яку зняли із штурмовиків “Вuccaneer”, були оснащені стратегічні бомбардувальники “Vulcan”. При завдаванні бомбових ударів по аеродрому Порт-Стенлі вони активни- 
ми перешкодами придушили роботу РЛС ракетних комплексів "Roland” i “Tigercat", що здійснювали ППО аеродрому (Родионов, Б. \& Никитин, В. \& Новичков, Н. 1983, с. 79-81, 85).

Через недооцінку повітряної небезпеки командування британських ВМС організувало надійну тактичну розвідку в системі ППО. Внаслідок цього в зоні, яка перекривалась технічними засобами виявлення повітряних цілей і забезпечувала перехоплення літаками “Sea Harrier", аргентинська авіація все ж таки зуміла застосувати ПКР, причому з високою ефективністю. Через обмеженість боєкомплекту аргентинська авіація лише чотири рази застосувала авіаційні ПКР "Ехосеt” АМ.39. Успішність їх застосування складала 50\% - три 3 шести ракет влучили в ціль (берегових частин $25 \%$, одна 3 чотирьох вразила ціль).

Варто зазначити, що бойові дії з ведення ППО в англо-аргентинському конфлікті показали незахищеність підводних човнів від нападу повітряного противника. Так, під час атак британських вертольотів по підводному човну "Santa Fe" особовий склад здійснював ППО підводного човна не маючи засобів ураження повітряного противника, вів стрільбу по вертольотам із гвинтівок (Аргентинские подводные лодки... 2004). Можемо припустити, що якби на озброєнні “Santa Fe" були, наприклад, переносні ЗРК, то підводний човен міг би уникнути атак 3 боку британських вертольотів.

Аналіз організації ППО у ході англо-аргентинського конфлікту 1982 р. дозволив стверджувати наступне. Хоча командування ВМС Великобританії у Південній Атлантиці вважало, що створенням глибокоешелонованої оборони проти повітряного противника, який обмежений у виборі маршрутів польоту, буде гарантувати безпеку їх кораблям і суднам, проте, проблема ППО не була вирішена. Всіх втрат у ко- рабельному складі вони зазнали саме від авіації.

Висновки. Підсумовуючи зазначимо, вищенаведені факти свідчать, що для успішного проведення операції, аналогічної Фолклендській, корабельне угруповання повинно мати надійну систему ППО, яка має включати авіаційні засоби дальнього виявлення цілей на малих висотах. Тільки за наявності таких засобів сторона, що обороняється буде спроможною швидко підняти в повітря свої винищувачі для перехоплення літаків противника ще до того, як вони вийдуть на рубіж пуску ракет, і привести в бойову готовність інші засоби ППО. Широке застосування британськими ВМС засобів РЕБ частково було спричинене тим, що для прикриття кораблів вони не мали літаків дальнього радіолокаційного виявлення повітряних цілей. Хоча ППО британських кораблів за своєю суттю була протилітаковою, проте, вона виконувала ще й завдання ПРО. Велике значення у боротьбі з ПКР варто надавати РЕБ, яка в районі Південної Атлантики виступила не стільки як вид забезпечення, а як вид бойових дій, безпосередньо пов'язаний з ППО.

Успішні дії аргентинської авіації проти британських експедиційних сил показали ефективність в умовах РЕБ «старих» тактичних прийомів авіації - топ-мачтового бомбометання, штурмових ударів 3 малих висот із застосуванням авіаційних бомб і НКРСів. Особливо результативними такі дії будуть при завдаванні ударів 3 декількох напрямків.

У конфлікті в складі сил протиборчих сторін брали участь різні класи допоміжних суден, які також зазнавали атак з боку авіації. Хоча їх і озброювали засобами ППО, проте від повітряних ударів вони були практично беззахисними. Для підвищення бойової стійкості в умовах впливу 
засобів повітряного нападу противника виникає необхідність додатково озброювати їх ЗРК. Крім того, англо-аргентинський збройний конфлікт засвідчив важливість у вирішенні завдань ППО завчасного (раннього) попередження про повітряну небезпеку та взаємопов'язаної і дієвої радіоелектронної та повітряної розвідки.

\section{СПИСОК ДЖЕРЕЛ ТА ЛІТЕРАТУРИ}

Аргентинские подводные лодки в Фолклендской войне 1982 года. 2004. Альманах «Войны. История. Факты». 2 (6), июнь : URL : http:/www.almanacwhf.ru/?no=6\&art=5 [дата зверн.: 17.09.2017].

Бадах, Ю.Г. 2003. Флоти у локальних війнах і збройних конфліктах другої половини XX - початку ХХІ століть. Київ: НАОУ. 168 с.

Военно-морской словарь. 1990. Пред. Гл. ред. комиссии В. Н. Чернавин. Москва: Воениздат. $511 \mathrm{c.}$

Военный энциклопедический словар. 1983. Пред. Гл. ред. комиссии Н. В. Огарков. Москва: Воениздат. 863 с.

Галкин, Ю. 1983. Противовоздушная оборона английских экспедиционных сил (в ходе англо-аргентинского конфликта). Зарубежное военное обозрение. 3. С. 64-67.

Родионов, Б.И., Новичков, Н.Н. 1987. Крылатые ракеты в морском бою: по материалам открытой зарубежной печати. Москва: Воениздат. 215 с.

Родионов, Б. \& Никитин, Е. \& Новичков, Н. 1983. «Радиоэлектронная война» в Южной Атлантике. Морской сборник. 1. С. 77-85.

Рябчиков, А. В. 2001. Применение ПКР в локальных войнах. Ракетная техника. 10 октября. URL : http://rbase.new-factoria.ru/pub/article_pkr/page6.shtml [дата зверн.: 27.10.2019].

Татарков, Д. 2007. Конфликт в Южной Атлантике: Фолклендская война 1982 г. : Монография. Киев. 416 с.

Татарков, Д. Б. 2013. Міжвидові угруповання військ (сил) в англо-аргентинському збройному конфлікті 1982 року: автореф. дис. ... канд. іст. наук: 20.02.22 / Нац. ун-т оборони України. Київ. 20 с.

Фолклендская война 1982. История войн. URL : http://historiwars.narod.ru/Index/XXv/ Folk/folkmain.htm [дата зверн.: 21.04.2020].

Фурман, I. I. 2006. Самостійні дії флотів в локальних війнах та збройних конфліктах (1967-1988 рр.): дис. ... канд. іст. наук: 20.02.22 / Київ. Нац. акад. оборони України. 192 с.

Хурс, И.К. 1987. Некоторые вопросы обеспечения устойчивости корабельных соединений в море. Военная мысль. 1. С. 32-41.

\section{REFERENCES}

Argentine submarines in the Falklands War of 1982. 2004. [Argentine submarines in the Falklands War of 1982]. Almanah «Voynyi. Istoriya. Faktyi". 2 (6), iyun. URL : http://www. almanacwhf.ru/?no=6\&art=5 [Accessed: 17.09.2017]. [in Russian]. 
Badakh, Yu. H. 2003. Floty u lokalnykh viinakh i zbroinykh konfliktakh druhoi polovyny 20 pochatku 21 stolit [Fleets in local wars and armed conflicts of the second half of the 20th - early 21st centuries]. Kyiv: NUOU. 168 s. [in Ukrainian].

Voenno-morskoy slovar [Naval Dictionary]. 1990. Pred. Gl. red. komissii V. N. Chernavin. Moskva: Voenizdat. 511 s. [in Russian].

Voennyiy entsiklopedicheskiy slovar. [Military Encyclopedic Dictionary]. 1983. Pred. Gl. red. komissii N. V. Ogarkov. Moskva: Voenizdat. 863 s. [in Russian].

Galkin, Yu. 1983. Protivovozdushnaya oborona angliyskih ekspeditsionnyih sil (v hode anglo-argentinskogo konflikta) [Air defense of the British Expeditionary Force (during the conflict between Argentina and United Kingdom)]. Zarubezhnoe voennoe obozrenie. 3. S 64-67. [in Russian].

Rodionov, B. I. \& Novichkov, N. N. 1987. Kryilatyie raketyi v morskom boyu: po materialam otkryitoy zarubezhnoy pechati [Cruise missiles in naval combat: based on materials from an open foreign press]. Moskva: Voenizdat. 215 s. [in Russian].

Rodionov, B. \& Nikitin, E. \& Novichkov, N. 1983. "Radioelektronnaya voyna" v Yuzhnoy Atlantike ["Electronic warfare" in the South Atlantic]. Morskoy sbornik. 1. S. 77-85. [in Russian].

Ryabchikov, A. V. 2001. Primenenie PKR v lokalnyih voynah [Anti-ship missiles using in local wars]. Raketnaya tehnika. 10 oktyabrya. URL : http://rbase.new-factoria.ru/pub/article_pkr/page6. shtml [Accessed: 27.10.2019]. [in Russian].

Tatarkov, D. 2007. Konflikt v Yuzhnoy Atlantike: Folklendskaya voyna 1982 g. : Monografiya. [Conflict in the South Atlantic: The Falklands War of 1982: Manuskript]. Kyiv. 416 s. [in Ukrainian].

Tatarkov, D. B. 2013. Mizhvydovi uhrupovannia viisk (syl) v anhlo-arhentynskomu zbroinomu konflikti 1982 roku [Join Task Force are in the Anglo-Argentine armed conflict in 1982]: avtoref. dys. ... kand. ist. nauk: 20.02.22 / Nats. un-t oborony Ukrainy. Kyiv. 20 s. [in Ukrainian].

Folklendskaya voyna 1982. [The Falklands War of 1982]. History of wars. URL : http:// historiwars.narod.ru/Index/XXv/Folk/folkmain.htm [Accessed: 21.04.2020]. [in Russian].

Furman, I. I. 2006. Samostiini dii flotiv v lokalnykh viinakh ta zbroinykh konfliktakh (19671988 rr.) [Development of fleet military art in local wars and conflict during independent fleet operation (1967-1988)]: dys. ... kand. ist. nauk: 20.02.22 / Kyiv. Nats. akad. oborony Ukrainy. 192 s. [in Ukrainian].

Hurs, I.K. 1987 Nekotoryie voprosyi obespecheniya ustoychivosti korabelnyih soedineniy v more [Some issues of ensuring the reliability of naval formations at sea]. Voennaya myisl. 1. S. 32-41. [in Russian]. 
Andrukh O.O., Master of Public Administration, a candidate for a PhD in History,

The National Defense University

of Ukraine named after Ivan Cherniakhovskyi

(Kyiv, Ukraine)

ORCID: https://orcid.org/0000-0002-3594-5499

\section{FEATURES OF AIR DEFENSE BY SURFACE SHIP GROUPS IN THE FALKLANDS WAR OF 1982}

The article deals with experience of the organization of air (missile) defense of British ships in the South Atlantic during the Falklands War of 1982. After analyzing the organization of air defense during this conflict we can say that the command of the British Navy in the South Atlantic considered that the creation of deep-layered defense against the limited in the choice of routes air enemy will ensure the safety of their ships and vessels, but it has not been resolved. It is defined that in order to successfully conduct military operations at sea, a surface ship group must have a reliable air defense system, which must include aircraft for long-range detection of targets at low altitudes. The air defense of British ships was essentially antiaircraft one, but it also performed the task of missile defense. In the fight against antiship missiles great importance should be given to electronic warfare, which in the South Atlantic has acted not only as a type of support, but also as a type of combat, directly related to air defense. It is shown actions of the British surface ship group on the air defense frontiers, tactics and the results of the use of various means of destroy air enemies. At the same time, it is revealed the successful actions of the Argentine air force against the British expeditionary forces, showed effectiveness of "old" aviation tactics in the conditions of electronic warfare - masthed bombing, assault strikes from low altitudes using air bombs and unguided missile projectiles. It is proved that in order to increase resilient force under the influence of enemy air attack means, it is necessary to additionally arm them with antiaircraft missile systems. Simultaneously, this conflict demonstrated the importance of early warning of air danger and interconnected and effective electronic and air reconnaissance in the task of air defense.

Keywords: Falklands War of 1982, means of air attack, air defense, missile defense, air defensein-depth system. 